\title{
Exploration of the strategy of incorporating local music into music teaching
}

\author{
Chen Jun ${ }^{1, a}$, Zhu JiaJun ${ }^{1, b}$ \\ ${ }^{1}$ Jiangxi Science \& Technology Normal University, Nanchang, Jiangxi, 330013, China \\ a 974034152@qq.com, b20651816@qq.com
}

Keywords: Music teaching; local music; integration strategy

\begin{abstract}
Local music is the essence of national regional music, but after entering the new century, a wide range of music for local music heritage and development of the formation of a huge impact. So in the school music teaching appropriate to join the local music can to a certain extent, promote the local music heritage and carry forward. But how to integrate the local music into the music teaching is the problem of the current music teaching. We need to explore the music teaching in detail, and elaborate how to effectively join the local music effective strategy in the music teaching.
\end{abstract}

\section{Introduction}

In the process of school music teaching, the integration of local music has a certain positive significance. First of all, students can promote the aesthetic ability of the local music in the introduction of local music teaching can make students fully experience the charm of local music, but also to further expand the student's music vision, in the process of learning and experience of local music students continue to improve aesthetic ability [1]. Second, we can promote the innovation of music curriculum. Schools and teachers are actively exploring local music, providing a breakthrough for the effective reform of local school music courses. Finally, promote the promotion and transmission of local music culture. The development of local music teaching has positive significance to the promotion of local music culture and promotes the protection and development of intangible cultural heritage of local music.

\section{Introduce local instruments into the music classroom}

China's border areas of ethnic minorities geographical location, unique climate, gave birth to a unique music, the ancestors of local materials made of a variety of ethnic musical instruments, such as the Zhuang's horse bone Hu, Tianqin, Dong Dong, Miao Lusheng and so on. In order to better play their own expertise, improve the practicality of music learning, usually the instrument is divided into major and elective two, in addition to the need to elect a local musical instruments, such as lyre or pipa. In addition, some students because some students because of their own conditions are not suitable for vocal music, teachers can guide students to choose other national musical instruments. Thus through a series of communication and exchange, you can change the musical instrument learning atmosphere, to facilitate teaching to carry out daily teaching activities. On the arrangement of teachers, you can follow the "please come in" way, some very unique musical instruments, the school's teachers are not good at school can give full play to social resources, such as hiring local cultural center artists enter the school musical instruments teaching activities. National musical instruments into the campus on the one hand to promote the spread of regional culture, on the other hand also makes our campus culture has been greatly enriched. Schools can also be out of the campus for the region and social services, to carry out recreational activities for people in the region to bring happiness, increase the influence of the school. And the success of the school band's performance will further enhance the confidence of students in the region's musical instruments. This school actively set up a school-level performance team, first of all for the school to provide a practice, practice platform and opportunities for students to master the technology has a place, but also classroom learning and practical combination of organic, The inheritance and development of regional music. 


\section{The local native folk songs into the classroom}

Ethnic groups, their own folk and folk songs there are some differences, such as the Zhuang, they exist a large number of nationalities, types, in content and form there are many, such as life, ceremony, brother, current affairs, Ancient songs, narrative songs [2]. As a result of the dialect, Zhuang folk songs tone color "martial" numerous, from the style is divided into South Road, West Road, Road and so on, from the lattice classification of the West, Canada, London and so on. In addition, there are single, double, three folk songs. For example, the Dong people can sing and dance, not only have world-renowned Dong songs, but also the river song, bass, etc., each type of folk songs are distinctive. Folk songs of various ethnic groups have been active in the amateur life of the local people and have brought great joy to people. At the same time, the diverse folk songs have provided strong resources guarantee for the teaching activities of the school district music. At the same time these years our national government is working to strengthen the protection of intangible cultural heritage, local schools to actively introduce local native folk songs. Some schools formed a native folk performance team, the school teacher's guidance and the efforts of students, and constantly improve the team's performing strength, and actively participate in regional or national folk music performances, recognized by experts to expand the area of native folk songs Influence. The local government needs to increase support, to facilitate the development of space and platform.

\section{Introduce local opera into the classroom}

The unique geographical position of each ethnic region has shaped a distinctive national culture, and gradually created a regional opera. For example, Guangxi has different landforms, and local folk operas such as Gui opera, Zhuang drama, color tone, Dong opera, Wenchang, and tea picking are also formed. All the above folk opera in clothing, singing, performance forms, accompaniment musical instruments, there are some differences, each with their own characteristics. Zhuang drama a total of South Road, drama, division play, South Road, drama three drama. The instrument used in the performance of the play is usually Ma Koo-hu, singing in local Zhuang language, which is an opera developed in the form of local art of music, dance, rap, literature and so on. species. Guangxi Gui opera contains a variety of repertoire, and even civil existence "the size of the miscellaneous 800 out of" argument. Because the emergence and continuation of the opera are all closely related to the Chinese opera and the opera, there is a close relationship between the opera and the opera. Therefore, there are some similarities between the opera repertoire and the skin-yellow system in many cases. Another kind of Guangxi is the more common local opera is the color tone. In the actual performance of the process, the fan can also be used as weapons or tools, which fan access to the "universal tool", the performance is very important, Of the title. Dong opera is more prevalent in the Dong area, performing artists need to wear the local Dong costumes, the use of Dong language for singing. Liuzhou in Guangxi and Guilin and other regions also popular with a kind of drama - the text field. This type of opera performance artists need to have a certain singing, reading, doing, playing the basis of [4]. But many music school students do not have the appropriate knowledge and skills, and if each student is required to master a drama difficult to play some high to the students the current foundation and strength can not be achieved, but the school can learn by observing Or invite experts to organize lectures in the form or can achieve a certain effect. Schools can lead students to enjoy the performances of folk operas, observe and study in the process, the school can also invite the more famous local opera troupe to enter the campus for students to perform, invited the opera art into the campus theater lectures. Through this series of activities can expand students 'horizons, significantly enhance the students' stage expression. For the follow-up students of national drama learning and performance to lay a good foundation.

\section{Set up a reasonable elective course}

In the area of the school, the need to better meet the requirements of the times, cultivate a stronger social adaptability of the talent, the need to actively build a multi-level curriculum structure. 
According to the specific circumstances of a reasonable elective courses for the introduction of the local lay a good foundation and platform, the use of this platform can be successful local music smoothly into the music teaching. According to the guidance of this idea, many schools set up the corresponding courses, such as a college in Zhejiang Province in the four-year school in the additional "Zhejiang local music form", "Zhejiang music culture and history" elective courses. The local music elective courses have gradually become an important part of the school elective courses in the region, to a large extent to fill the music teaching deficiencies, improve the status of local music. The duration of these courses will be selected according to the students learning rules, students learn a year after the beginning of basic music elective, sophomore or third grade is appropriate, in a year, students have mastered the traditional music or other professional basis Knowledge, which can be achieved a depth of the effect of expansion. This arrangement not only allows students to learn and understand the specific content of local music, to expand the knowledge of students, but also greatly promoted the further development of local music and heritage. But also for the follow-up teaching reserve sufficient knowledge. Graduation of music school every year many students, the number of local music learning in the continuous improvement, which fully reflects the local music learning effect has been very pick up.

\section{Summary}

In summary, the study of local music for the regional cultural heritage has great positive significance, while the country also strongly supports the development of folk music culture. This region began to actively phase with the development of folk culture called for the introduction of local music, music teaching. But for the various regions of the school, there is no adequate teaching of local music experience, which we have a detailed exploration. Through the above-mentioned elaboration, the school can introduce the regional opera, the local native folk song, the regional musical instrument and the local music curriculum and so on teaching in the music classroom, and so on, the teaching can obtain the remarkable result.

\section{References}

[1] Kang Xiaodan. Explore the music in the teaching of local music into the local strategy [J]. Art and technology, 2016,06: 398.

[2] Li Jun. The Exploration of Introducing Local Music into Music Teaching in Colleges and Universities - Taking Taizhou University as an Example [J]. Art Research, 2011,02: 91-92.

[3] Wu Can, Chen Xing. Gannan tea opera into the local teacher music education value and path [J]. Educational Theory and Practice, 2011,21: 39-40.

[4] NONG Xing-guang. A Study on the Incorporation of Local National Music Culture into the Teaching System of Music in Teachers' College - Taking the Teaching of Art Department of Guangxi Normal University for Nationalities as an Example [J]. 